characteristics of dynamics of students' assessing attitudes, forming in a new context of civilizational social development, determined by the processes of globalization, new information and communication technology, and the virtualization of the modern communicative space.

Keywords: system of education, family, national security, globalization, information and communication technology, value consciousness, value orientations, youth, virtual reality

ЕЖОВ Дмитрий Александрович - кандидат политических наук, доцент, старший научный сотрудник Центра политологических исследований Департамента политологии и массовых коммуникаций Финансового университета при Правительстве РФ (125993, Россия, г. Москва, Ленинградский np-кm, d. 49; president@lenta.ru)

\title{
ДОСТОВЕРНОСТЬ ОСВЕЩЕНИЯ ПОЛИТИЧЕСКОЙ СИТУАЦИИ В РОССИИ СОВРЕМЕННЫМИ СМИ В ВОСПРИЯТИИ СТУДЕНЧЕСКОЙ МОЛОДЕЖИ
}

Аннотация. В статье предлагается анализ результатов всероссийского опроса, проведенного в рамках изучения социально-политических настроений студенческой молодежи. Внимание автора концентрируется на проблеме оценки достоверности освещения политических событий современными СМИ в восприятии молодежного сегмента аудитории. Оценивается уровень достоверности информации, распространяемой посредством телевидения и глобальной сети Интернет.

Ключевые слова: политическая ситуация, средства массовой информации, студенческая молодежь, телевидение, Интернет

$\mathrm{M}$ ногообразие источников получения информации, вызванное развитием интернет-технологий и средств массовой коммуникации, предопределяет актуальность постановки вопроса о степени достоверности ретранслируемого политического контента. Не оспаривая доминанту субъективизма в восприятии соответствующих сведений, мы считаем вполне очевидным факт его дифференцированного отображения в различных социовозрастных группах. Особое значение среди последних имеет сегмент студенческой молодежи, ограничивающийся возрастными рамками от 18 до 24 лет, ввиду особенностей усвоения его представителями норм политической культуры. Дальнейшие авторские суждения основаны на результатах всероссийского опроса, проведенного Финансовым университетом при Правительстве РФ в 2018 г. по репрезентативной выборке в рамках осуществления научно-исследовательской работы, направленной на изучение социально-политических предпочтений студенческой молодежи.

Результаты всероссийского опроса во многом подтверждают распространенное мнение, основанное на восприятии молодежного сегмента социума как ярчайших представителей круга активных пользователей глобальной сети Интернет и потребителей распространяемых ею информационных продуктов. Так, в ходе проведенного исследования на вопрос: «Какими медиаресурсами Вы пользуетесь?» - 58,75\% предпочли ответить «Интернетом», и 33,17\% респондентов выбрали ответ «телевидение». Для полноты картины приведем данные, свидетельствующие, что радио предпочитают $1,75 \%$ опрошенных; печатную прессу - 0,42\%, всеми доступными источниками пользуются 5,17\%; а 0,75\% 
респондентов не пользуются медиаресурсами в принципе. Полагаем, столь очевидная популярность Интернета среди студенческой молодежи вызвана не только развитием и постоянным совершенствованием соответствующих технологий, но также удобством использования интернет-ресурсов и их оперативной доступностью. В подтверждение сказанного следует добавить, что 29,42\% опрошенных узнают информацию о действиях руководства страны из социальных сетей, в т.ч. из официальных аккаунтов в Twitter и Facebook представителей власти, и примерно равное число принявших участие в опросе $(25,25 \%$ и $24,29 \%$ соответственно) - из аналитических программ и вечерних новостей. Иные источники информации оказались не столь популярными. Так, заявления официальных лиц рассматривают в качестве источника информации 7,58\% опрошенных, специальные репортажи $-6,67 \%$, а ежегодные послания Президента РФ Федеральному собранию РФ - всего $0,33 \%$.

В ответах на вопрос об объективности предоставления информации со стороны СМИ доминирует скептицизм. Так, 44,08\% участников опроса склонились к ответу «скорее нет, чем да»; 24,58\% уверенно ответили «нет»; 24,92\% полагают, что СМИ подают информацию скорее объективно, чем необъективно; и лишь $6,42 \%$ твердо считают, что информация современными медиа ретранслируется вполне объективно. Таким образом, мы видим, что с учетом колеблющихся категорий среди студенческой молодежи превалирует относительно низкий уровень доверия к средствам массовой информации.

Наибольший интерес представляют результаты проведенного опроса в части оценки достоверности освещения политической ситуации в России современными СМИ. Респондентам было предложено оценить по 5-балльной шкале степень достоверности освещения событий следующими СМИ: газета «Известия», интернет-издание «РБК», радиостанция «Вести $F M »$, телеканал «Первый канал», газета «Коммерсантъ», интернет-издание «Газета. $R u »$, радиостанция Business FM, телеканалы «Россия 1» и «Россия 24», газета «Ведомости», интернет-издание Lenta.ru, радиостанция «Русское радио», телеканал $R T$ (Russia Today), газета «Российская газета», интернет-издание Life, радиостанция «Европа Плюс», телеканал НТВ, газета «Новая газета», интернет-издание Meduza, радиостанция «Эхо Москвы», телеканал «Дождь». Симптоматично, что в большинстве случаев значительная часть респондентов полагают, что достоверность освещения в СМИ тяготеет к нулевой. В то же время отдельные примеры весьма показательны, и они позволяют констатировать наличие как минимум двух показательных фактов, побуждающих сделать определенные выводы.

Первый из них мы склонны рассматривать в контексте довольно интересного с исследовательской точки зрения результата, демонстрируемого оценочными мнениями в отношении «Первого канала» (большая часть акций канала принадлежат Росимуществу, Национальной медиа группе и бизнесмену Р. Абрамовичу), а также государственных телеканалов «Россия 1» и «Россия 24», владельцем которых является ВГТРК. Объединяет эти СМИ то, что в массовом сознании они традиционно ассоциируются с инструментами государственной пропаганды. Если «Первому каналу» в освещении информации о политической ситуации в России полностью не доверяют 20,68\% опрошенных (при этом нужно заметить, что это самый низкий антирейтинг по результатам исследования по сравнению с другими медиаресурсами, предложенными для оценки), промежуточные показатели в рамках предложенной шкалы в целом сопоставимы. К примеру, как полностью достоверное освещение политической ситуации в России «Первым каналом» оценивают $12,01 \%$ опрошенных, а в целом достоверным - 13,26\%. Идентичная картина 
формируется в отношении каналов «Россия 1» и «Россия 24» (в анкете эти два канала были объединены в один вопрос). В данном случае 22,77\% опрошенных посчитали ретранслируемую информацию абсолютно недостоверной, $11,93 \%$ - абсолютно достоверной, а 14,76\% - в целом достоверной. В то же время официальный печатный орган Правительства РФ «Российская газета», согласно результатам исследования, имеет антирейтинг достоверности в $47,71 \%$, а полностью достоверной публикуемую в нем информацию считают всего лишь 8,5\% опрошенных. На основании изложенного выше полагаем, что совокупная степень восприятия информации, ретранслируемой проправительственными СМИ, как достоверной фиксируется в среде студенческой молодежи на относительно стабильном и высоком уровне. При этом приоритет отдается тем средствам массовой информации, которые имеют больше возможностей и ресурсов в условиях видеократии, или, другими словами, тем, чья продукция представляется наиболее зрелищной.

Второй факт коррелирует с темой популярности и востребованности Интернета как медиаресурса среди студенческой молодежи. Результаты опроса демонстрируют, что в наибольшей степени в качестве высоко достоверного респонденты оценивают контент, распространяемый интернет-изданием Meduza, зарегистрированным в Латвии. Так считают 15,18\% опрошенных при ярко выраженном антирейтинге в 33,19\%. Второе место по оценке степени достоверности среди интернет-изданий занимает «РБК» $(10,68 \%$ и 33,86\% соответственно); третье - Lenta.ru (9,76\% и 30,61\%). Основываясь на изложенном, полагаем, что, несмотря на популярность Интернета как медиаресурса, уровень достоверности размещаемой в нем информации воспринимается опрошенными как более низкий по сравнению с контентом, распространяемым традиционными источниками (в большей степени - телевидением). В пользу сделанного вывода свидетельствует сравнение антирейтингов СМИ с точки зрения оценки достоверности информации.

Таким образом, можно констатировать сохранение относительно высокого уровня доверия к информации, ретранслируемой традиционными СМИ в среде студенческой молодежи, несмотря на возрастающую популярность сети Интернет. В то же время фиксируемая степень достоверности контента, распространяемого в сети Интернет, актуализирует вопрос о поиске форм презентации официальной повестки дня в рамках соответствующего медиаресурса для молодежной аудитории.

Статья подготовлена по результатам исследований, выполненныхзасчет бюджетныхсредств по государственному заданию Финансовому университету при Правительстве РФ. 
EZHOV Dmitriy Aleksandrovich, Cand.Sci. (Pol.Sci.), Associate Professor, Senior Researcher of the Centre of Political Studies of the Department of Political Science and Mass Communications, Financial University under the Government of the Russian Federation (49 Leningradsky Ave, Moscow, Russia, 125993; president@lenta.ru)

\section{RELIABILITY OF COVERAGE OF THE POLITICAL SITUATION IN RUSSIA BY MODERN MEDIA IN THE PERCEPTION OF STUDENTS}

Abstract. The article offers an analysis of the results of the all-Russian survey conducted in the framework of studying the socio-political attitudes of students. The attention of the author focuses on the problem of assessing the reliability of covering political events by modern media in the perception of the youth segment of the audience. The article assesses the level of reliability of information disseminated through television and the global Internet.

Keywords: political situation, mass media, students, television, Internet 